\section{Trotsenko Ye., Brzhezitsky V., Protsenko 0., Chumack V., Haran Ya.}

\title{
SIMULATION OF PARTIAL DISCHARGES UNDER INFLUENCE OF IMPULSE VOLTAGE
}

Проведено схемотехнічне моделювання іонізаційного пробою твердого діелектрика з частковим розрядом у газовому включенні. Запропоновано декілька способів схемотехнічного моделювання пробою газового включення при частковому розряді. Встановлено, що при впливі повного грозового імпульсу напруги на діелектрик в газовому включенні виникають інтенсивні часткові розряди, як на фронті імпульсу, так і на його спаді.

ключові слова: схемотехнічне моделювання, частковий розряд, імпульсна напруга, вищі гар моніки напруги.

\section{Introduction}

Partial discharges in the insulation of high voltage electrical equipment gradually lead to deterioration of the insulation properties, its physical destruction and, ultimately, to breakdown. In addition, partial discharges can lead to flashover of insulation. For example, partial discharges in one insulator can lead to flashover of the whole suspension insulator string [1]

According to GOST 20074, a partial discharge is an electrical discharge that shunts a part of the insulation between electrodes located at different potentials. In practice, partial discharges are local electrical breakdowns of weakened areas of solid insulation, such as gas cavities (or cavities of a liquid dielectric in solid insulation).

The presence of partial discharges in high voltage electrical equipment indicates internal defects of its insulation. Therefore, according to current standards, electrical equipment is subjected to partial discharge tests.

In addition to alternating voltage of various frequencies, partial discharges are also measured with damped alternating voltage and direct current voltage [2]. As will be shown later, the authors of the article consider it expedient to proceed to partial discharge measurements also in tests with applied impulse voltage.

\section{The object of research and its technological audit}

The object of research is: an equivalent circuit for a dielectric with a weakened insulation (for example, with a gas cavity) with a partial discharge. The test with partial discharge measurement by application of alternating voltage is one of the main methods of diagnostics and non-destructive tests. To register the characteristics of partial discharges, special equipment is used with software for processing the results of measurements [2], usually with some steady-state alternating voltage. Depending on the state of the insulation, the intensity of partial discharges may not be significant at an alternating voltage, while for impulse voltages, their intensity should increase greatly.
It should be noted that, according to GOST 1516.2, the application of impulse test voltage does not necessarily end with a breakdown of the electrical equipment insulation or the absence of breakdown. There may be a partial breakdown of insulation, in which not all insulation of electrical equipment will be damaged, but only some of its part. It is quite difficult to detect such damage in accordance with GOST 1516.2, but registration of partial discharges will allow this to be detected by increasing their intensity.

The use of existing technical means for measuring the characteristics of partial discharges at alternating voltage is not acceptable for the task in question. Therefore, it is preliminary necessary to carry out computer simulation of partial discharges when the impulse voltage is applied.

\section{The aim and objectives of research}

The main aim of the article is analysis of the partial discharge process in insulation under the influence of impulse voltage with a help of circuit simulation software. To achieve this aim, the following tasks are formulated:

1. Creation of a circuit simulation model of a dielectric with gas cavity with partial discharge.

2. Determination of the operability and applicability of the model under the influence of alternating voltage.

3. Study of partial discharge model under the influence of impulse voltage and the formulation of conclusions.

\section{Research of existing solutions of the problem}

Article [3] is considered the first publication devoted to the modeling of partial discharges in gas-insulated insulation. In the same paper, a capacitive equivalent circuit for a dielectric with a gas cavity is presented. A brief history of further modifications of the capacitive equivalent circuit for a dielectric with gas cavity with a partial discharge is given in [4].

It is shown in $[5,6]$ that the presence of higher voltage harmonics can lead to an increase in the intensity of partial discharges. 
It is shown in [7-9] that when an impulse voltage is applied to a sample of insulation, a significant number of partial discharge pulses occur. It is not electric power equipment subjected to an impulse voltage, but individual insulation samples: oil/polypropylene film [7], oil-impregnated paper [8], silicone gel [9]. In general, articles [7-9] disprove the assertion [10], according to which one or two partial discharges are produced when an impulse voltage is applied. It is shown in [8] that hundreds of partial discharges occur when switching voltages are applied to an insulation sample.

In general, in the field of modeling partial discharges at alternating voltage with the help of circuit simulation programs, great results have been achieved. In addition to this, in [11, 12], modeling and partial discharge measurement systems are also carried out with varying degrees of detail.

Thus, the results of the analysis allow to conclude that the problems of modeling partial discharges in the insulation of electrical equipment under the influence of impulse voltage have not yet been studied sufficiently.

\section{Methods of research}

To achieve objectives that are set such research method are applied: circuit simulation on a personal computer. The main material of the research is a capacitive equivalent circuit for a dielectric with a gas cavity with a partial discharge.

\section{Research results}

Schemes for determining the shape of partial discharges in gas cavity when subjected to different voltage are shown in Fig. 1. These schemes correspond to the traditional approach for studying partial discharges [3, 13]. The simulation is performed in the Micro-Cap Evaluation/Student Version [14].

In Fig. $1 E_{1}$ - functional voltage source; $R_{1}$ - internal resistance of the voltage source; $C_{1}$ - capacitance of dielectric, without gas cavity section; $C_{2}$ - capacitance of the section of the dielectric connected in series with gas cavity; $C_{3}$ - gas cavity capacitance. The remaining elements simulate a spark gap, simulating the breakdown of the gas cavity. These elements are listed below.

In Fig. 1, $a X_{1}, X_{2}$ - Schmitt triggers; $S W_{1}, S W_{2}$ - voltage-controlled switches.

In Fig. 1, $b, c X_{1}, X_{2}$ - voltage comparators with hysteresis; $S_{1}$, $S_{2}$ - voltage-controlled switches with hysteresis.

In Fig. 1, $c V_{1}, V_{2}$ - reference voltage sources. It is assumed that the resistance of the switches $S W_{1}, S W_{2}, S_{1}$ and $S_{2}$ in the open state is $100 \mathrm{M} \Omega$, and in the close state is $1 \Omega$. The internal resistance of the voltage source is $1 \Omega$.

The schemes in Fig. 1 show different approaches to circuit simulation of breakdown. In particular, the circuit in Fig. 1, $a$ corresponds to the approach proposed in [12], and the scheme in Fig. 1, $b, c$ corresponds to the approach proposed in $[15,16]$. All the graphs that will be shown below are obtained in the model shown in Fig. 1, $c$.

Before studying the effect of impulse voltage on the insulation model with gas cavity, the model is tested using an alternating voltage. The results are shown in Fig. 2. It should be noted that, the results are shown on the same plot, but with different vertical axis scales. The blue color shows the voltage applied to the dielectric. The red color shows the voltage on gas cavity in solid insulation.
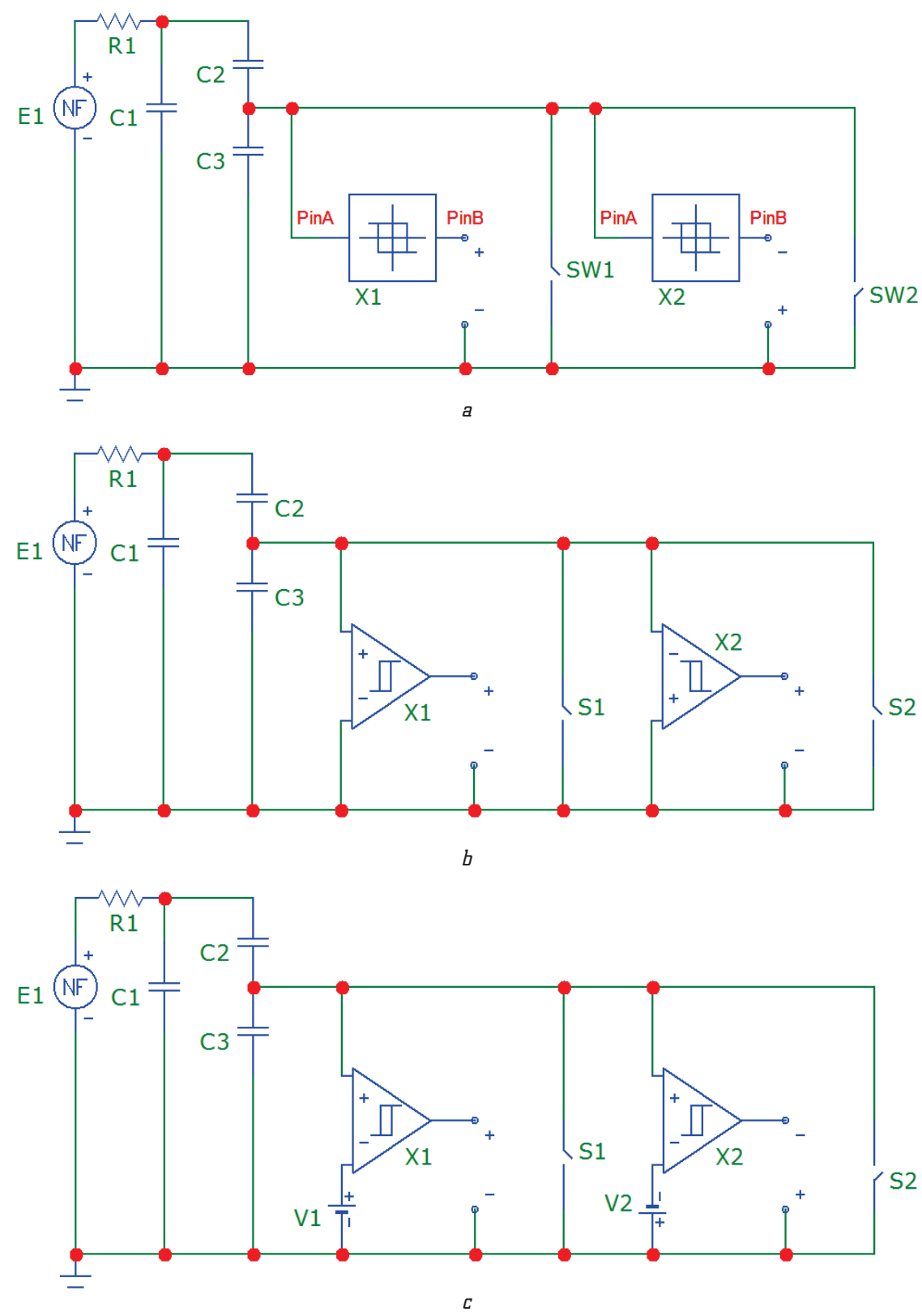

Fig. 1. Simulation of a dielectric with gas cavity with a partial discharge using: $a$ - a Schmitt trigger and a voltage-controlled switch; $b$ - voltage comparator with hysteresis and a voltage-controlled switch with hysteresis; $c$ - a voltage comparator with hysteresis and a voltage-controlled switch with hysteresis, as well as a reference voltage source 
Fig. 2, $a$ corresponds to applying only the main harmonic of the voltage with the amplitude $10000 \cdot \sqrt{2} / \sqrt{3} \mathrm{~V}$. This corresponds to the case of an undistorted voltage curve. In practice, non-sinusoidal regimes often occur. Fig. 2, $b, c$ correspond to the presence, in addition to the main harmonic, of the 5th harmonic voltage component, whose amplitude is $4.0 \%$ of the main harmonic. The phase shift of the 5th harmonic in Fig. 2, $b$ is $270 / 180 \pi \mathrm{rad}$, and in Fig. 2, $c$, respectively, 330/180 $\pi$ rad.
The curves in Fig. 2 show that the models in Fig. 1 reproduce user-specified values of the partial discharge inception voltage $(+800 \mathrm{~V})$ and the partial discharge extinction voltage $(+400 \mathrm{~V})$. Accordingly, for a negative half-cycle of a sinusoid, these values are $-800 \mathrm{~V}$ and $-400 \mathrm{~V}$. The simulation is performed at such values of the capacitances: $C_{1}=5000 \mathrm{pF} ; C_{2}=200 \mathrm{pF}$ and $C_{3}=600 \mathrm{pF}$. The graphs in Fig. 1, $a$ correspond to the traditional form of the voltage curve on a gas cavity at a partial discharge [13].
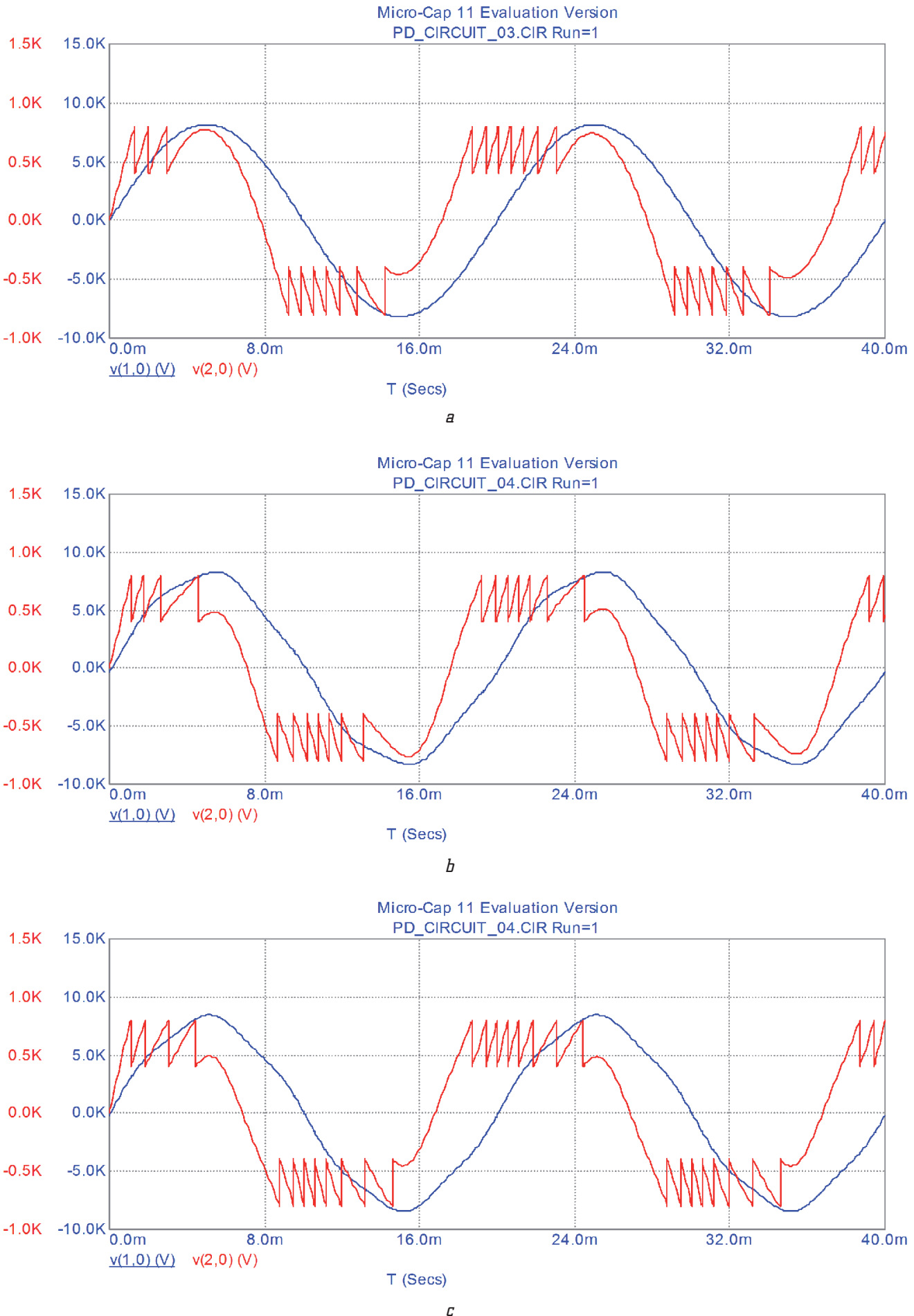

Fig. 2. Application of an alternating voltage to a dielectric with gas cavity with a partial discharge:

$a$ - effect of the main (1st) voltage harmonic; $b$ - effect of the 1st and 5th voltage harmonic without increasing the intensity of the partial discharges; $c$ - effect of the 1st and 5 th voltage harmonic with increasing the intensity of the partial discharges 
The curves in Fig. 2, $b, c$ show that even a small level of voltage harmonic distortion affect the shape of the partial discharges. In addition, at certain values of the phase shift of the harmonics, the intensity of the partial discharges can increase. For example, in Fig. 2, $a, b$ there are 14 partial discharges per one period, and in Fig. 2, $c$ already have 16 partial discharges per one period. Thus, with a help of this model, results are obtained that correspond to the statement $[5,6]$ on the influence of harmonic distortion on the increase in the intensity of partial discharges.

To test the model with impulse voltage, a full lightning impulse with $75 \mathrm{kV}$ amplitude and $1.2 / 50 \mu \mathrm{s}$ waveform is used. According to GOST 1516.3, this impulse is used for testing insulation of $10 \mathrm{kV}$ electrical equipment. To describe such aimpulse, the expression [17] is used:

$$
E_{1}=1.044 \cdot 75000 \cdot\left(e^{-1.400 \cdot 10^{4} \cdot t}-e^{-1.917 \cdot 10^{6} \cdot t}\right) .
$$

The results of applying the voltage impulse (1) to the object are shown in Fig. 3. As before, the voltage applied to the dielectric is shown in blue color. The red color corresponds to the voltage on gas cavity in solid insulation.

Fig. 3 shows that in gas cavity partial discharges occur both at the impulse front and on its tail. The number of partial discharges is too big for displaying them all on a same plot.

In Fig. 4 separately on an enlarged scale are shown the partial discharges, corresponding to the front of the applied impulse.

In Fig. 5, respectively, are shown the partial discharges, corresponding to the tail of the impulse.

As can be seen in Fig. 3-5, partial discharges of positive polarity occur at the impulse front, and partial discharges of negative polarity at the impulse tail. It should be noted that, the lightning impulse applied to the insulation has a positive polarity.

When the amplitude of the applied impulse is $75 \mathrm{kV}$, the number of partial discharges both at the front (Fig. 4) and at the tail (Fig. 5) of the impulse is 44. When the amplitude of the applied impulse voltage decreases, the number of partial discharges decreases too. For example, when the amplitude of the applied impulse is $50 \mathrm{kV}$, there are 29 partial discharges at the front and 28 discharges at the tail.

Thus, the results obtained with a help of the model show that when the impulse voltage is applied to the insulation sample, the intensity of the partial discharges increases greatly, both in the front region and in the tail region, which is similar to $[7,8]$.

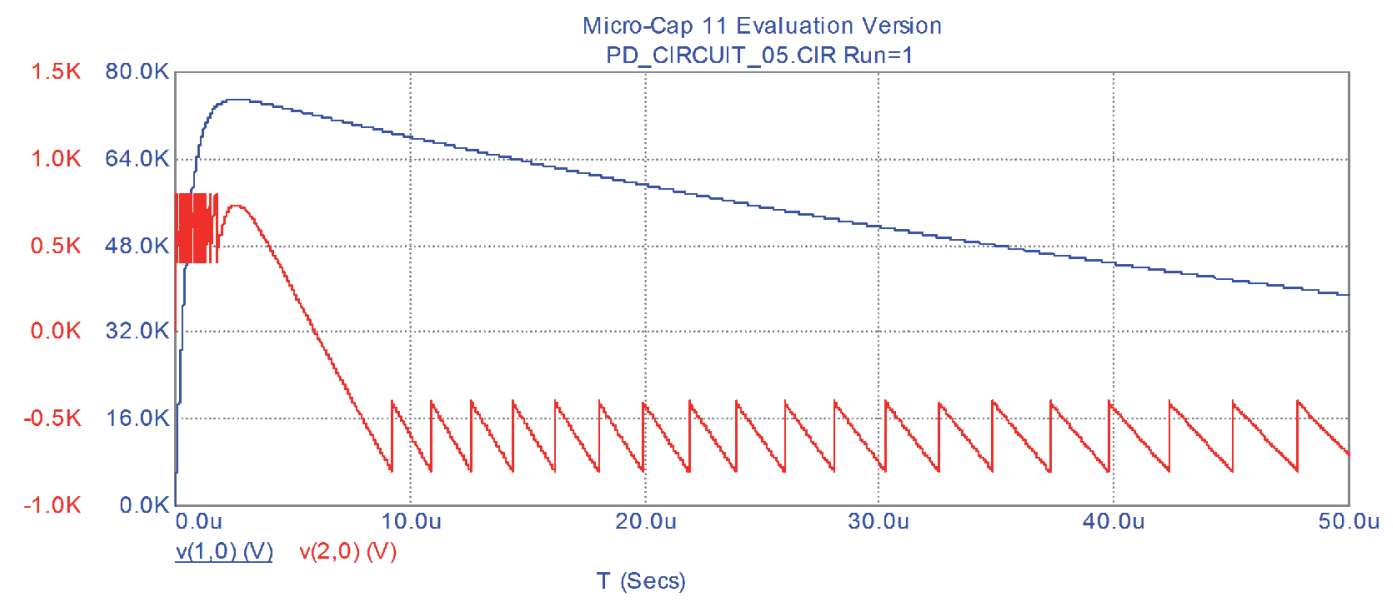

Fig. 3. Application of a full lightning impulse to a dielectric with gas cavity with partial discharge

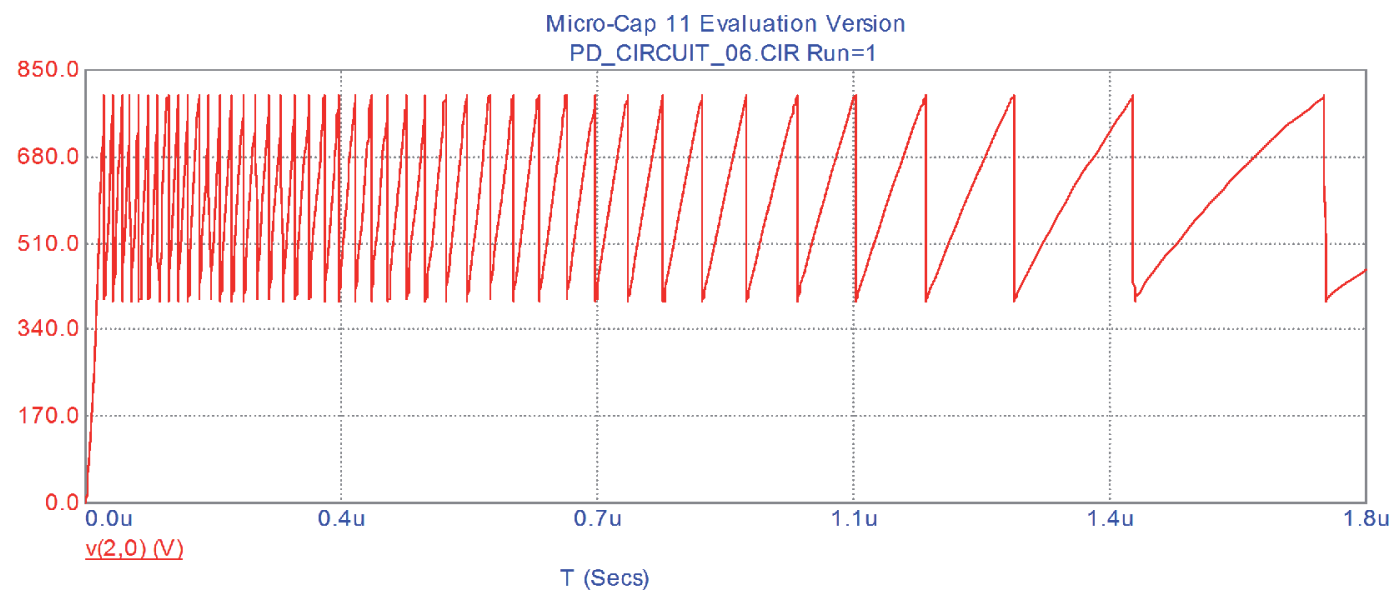

Fig. 4. Partial discharges in gas cavity (corresponding to the front of applied impulse) 


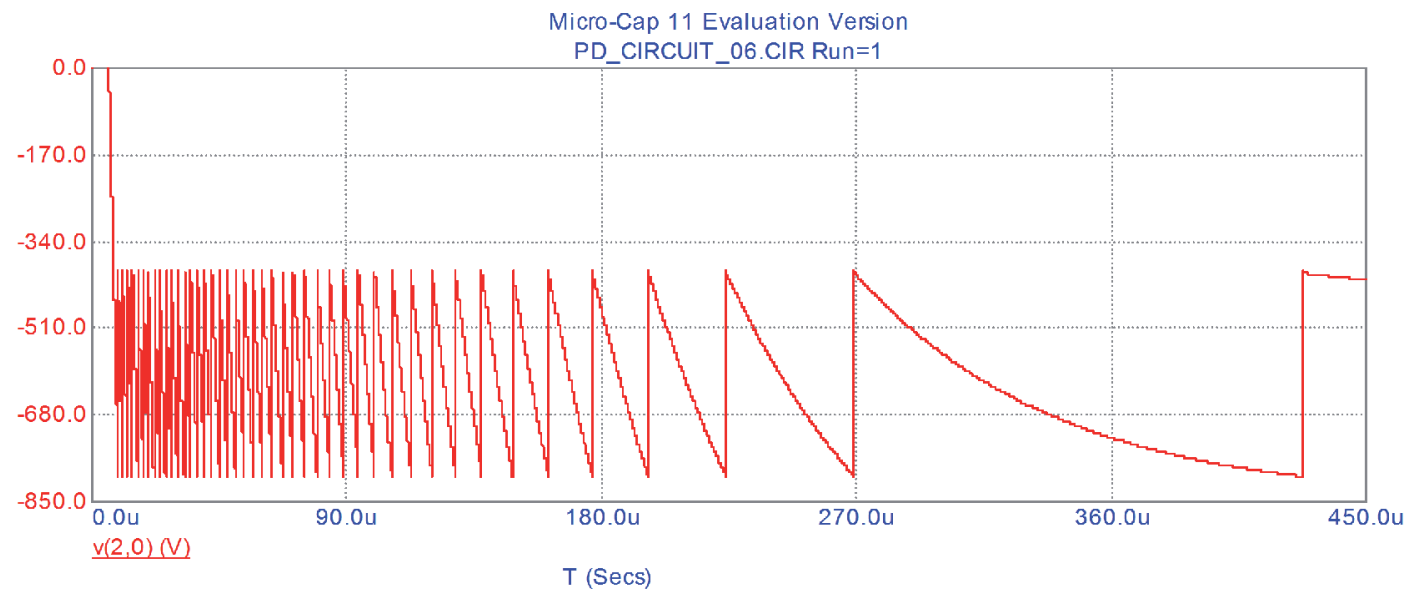

Fig. 5. Partial discharges in gas cavity (corresponding to the tail of applied impulse)

\section{SWOT-analysis of research results}

Strengths. The strengths of this research are: - the possibility of modeling the partial discharge phenomenon with the help of programs of circuit simulation. This is very important, because unlike a virtual experiment, a physical experiment requires a high-voltage laboratory, expensive equipment and a large staff of qualified personnel;

- unlike other studies, the proposed approach will allow to expand the possibilities of diagnosing the state of insulation using partial discharges.

Weaknesses. The weak sides of this research are:

- the exact number, the geometric dimensions of the gas cavities and their position in the solid dielectric are not known. The actual values of the capacitances in a three-capacitive equivalent circuit for a dielectric with gas cavity, respectively, are also not known. Therefore, models can be used more for qualitative rather than quantitative estimation of partial discharges under the influence of impulse voltage.

Opportunities. The additional opportunities that this research provides include:

- the possibility of further improvement of the model, including taking into account the effect of moisture content in insulation, the presence of several gas cavities and other factors or features;

- the possibility to optimize the experimental work in a high-voltage laboratory, having previously determined a further plan of experiments via models.

Threats. The results obtained via models always only approximate the results of the actual physical experiment. In view of the complexity of the phenomenon, the model does not take into account some of the features. For example, this refers to the statistical dispersion of characteristics and forms of cavities in insulation.

\section{Conclusions}

1. A circuit simulation model of a dielectric with a gas cavity with partial discharge has been created. The model includes three capacitances: $C_{1}-$ capacitance of dielectric, without gas cavity section; $C_{2}$ - capacitance of the section of the dielectric connected in series with gas cavity;
$C_{3}$ - gas cavity capacitance. It is shown how, by means of a combination of various elements, to simulate the breakdown of a gas cavity.

2. The operability of the model under the influence of alternating voltage is checked. It is established that the model reproduces the behavior of a real dielectric with gas cavity with partial discharges under the influence of an alternating voltage. The voltage curves on gas cavity reproduce user-specified values of the partial discharge inception voltage and the partial discharge extinction voltage. In addition, it is confirmed that voltage harmonic distortions lead to an increase in the number of partial discharges

3. A study of the model is carried out when it is subjected to a full lightning voltage impulse. As a result, it has been established that partial discharges occur in the gas cavity both at the impulse front and at its tail, and in considerable quantities. This allows to state that the diagnostics of the insulation condition using the measurement of the partial discharge characteristics under the influence of impulse voltage will be more informative. In particular, it will allow to detect partial breakdowns of insulation that occur during impulse tests and are absent in standard tests with application of alternating voltage. To carry out such measurements it is necessary to develop new techniques, equipment and diagnostic procedures.

\section{References}

1. A Study of the Causes of Electric Overlapping of the Middle Phase Insulator String of the Overhead Power Line / Brzhezitsky V. O. et al. // Research Bulletin of National Technical University of Ukraine « Kyiv Polytechnic Institute». 2011 Vol. 6. P. 36-41.

2. Eigner A., Rethmeier K. An overview on the current status of partial discharge measurements on AC high voltage cable accessories // IEEE Electrical Insulation Magazine. 2016. Vol. 32 No. 2. P. 48-55. doi:10.1109/mei.2016.7414231

3. Gemant A., Philippoff W. Die Funkenstrecke mit Vorkondensator // Zeitschrift für Technische Physik. 1932. Vol. 13, No. 9. P. 425-430.

4. Lemke E. A critical review of partial-discharge models // IEEE Electrical Insulation Magazine. 2012. Vol. 28, No. 6. P. 11-16. doi:10.1109/mei.2012.6340519

5. Florkowski M., Florkowska B. Distortion of partial-discharge images caused by high-voltage harmonics // IEE Proceedings Generation, Transmission and Distribution. 2006. Vol. 153, No. 2. P. 171-180. doi:10.1049/ip-gtd:20050008 
6. Impact of high voltage harmonics on interpretation of partial discharge patterns / Florkowski M. et al. // IEEE Transactions on Dielectrics and Electrical Insulation. 2013. Vol. 20, No. 6. P. 2009-2016. doi:10.1109/tdei.2013.6678848

7. Partial discharge characteristics of oil/polypropylene film with a needle-plate electrode excited by impulse voltages / $\mathrm{Li} \mathrm{Y}$. et al. // 2013 Annual Report Conference on Electrical Insulation and Dielectric Phenomena. 2013. P. 1225-1228. doi:10.1109/ ceidp.2013.6748256

8. Partial discharge characteristics of uniform gap in oil-impregnated paper insulation under switching impulse voltage / Deng J. et al. // IEEE Transactions on Dielectrics and Electrical Insulation. 2016. Vol. 23, No. 6. P. 3584-3592. doi:10.1109/ tdei.2016.005508

9. Do T., Lesaint O., Auge J.-L. Streamers and partial discharge mechanisms in silicone gel under impulse and AC voltages // IEEE Transactions on Dielectrics and Electrical Insulation. 2008 Vol. 15, No. 6. P. 1526-1534. doi:10.1109/tdei.2008.4712654

10. Vdoviko V. P. Chastichnye razriady v diagnostirovanii vysokovol'tnogo oborudovaniia. Novosibirsk: Nauka, 2007. 155 p.

11. A Matlab Simulink Model for a Partial Discharge Measuring System / Gunawardana S. D. M. S. et al. // 2015 Electrical Engineering Conference (EECon). 2015. P. 29-34.

12. Pahomov A. I. Metody i sredstva diagnostiki izoliatsii asinhronnyh dvigatelei sel'skohoziaistvennogo proizvodstva na osnove chastichnyh razriadov: Thesis Abstract of Doctor of Technical Sciences: 05.20.02. Krasnodar, 2005. 32 p.

13. Hochspannungstechnik: Theoretische und praktische Grundlagen / Beyer M. et al. Springer-Verlag Berlin Heidelberg, 1986. 362 p. doi:10.1007/978-3-642-61633-4

14. Micro-Cap 11. Electronic Circuit Analysis Program. Reference Manual. Sunnyvale, CA: Spectrum Software, 2014. 1040 p. URL: http://www.spectrum-soft.com/down/rm11.pdf

15. Trotsenko Y., Brzhezitsky V., Masluchenko I. Circuit simulation of electrical breakdown in air using Kind's equal-area criterion // Technology audit and production reserves. 2017. Vol. 3, No. 1 (35). P. 44-49. doi:10.15587/2312-8372.2017.102240

16. Babicheva A. A., Protsenko O. R., Trotsenko Ye. O. Modeliuvannia proboiu izoliatsiinoho promizhku iz zadanoiu voltsekundnoiu kharakterystykoiu // Mizhnarodnyi naukovo-tekhnichnyi zhurnal molodykh uchenykh, aspirantiv i studentiv «Suchasni problemy elektroenerhotekhniky ta avtomatyky». 2016. P. $357-359$

17. Brzhezitsky V., Trotsenko Y., Haran Y. Analysis and comparison of metal-oxide surge arrester models // Technology audit and production reserves. 2017. Vol. 6, No. 1 (38). P. 40-46.

\section{МОДЕЛИРОВАНИЕ ЧАСТИЧНЫХ РАЗРЯДОВ ЛРИ ВЛИЯНИУ ИМПУЛЬСНОГО НАПРЯЖЕНИЯ}

Проведено схемотехническое моделирование ионизационного пробоя твёрдого диэлектрика с частичным разрядом в газовом включении. Предложено несколько способов схемотехнического моделирования пробоя газового включения при частичном разряде. Установлено, что при воздействии полного грозового импульса напряжения на диэлектрик в газовом включении возникают интенсивные частичные разряды, как на фронте импульса, так и на его спаде.

Ключевые слова: схемотехническое моделирование, частичный разряд, импульсное напряжение, высшие гармоники напряжения.

Trotsenko Yevgeniy, PhD, Associate Professor, Department of High Voltage Engineering and Electrophysics, National Technical University of Ukraine «Igor Sikorsky Kyiv Polytechnic Institute», Ukraine, e-mail:y.trotsenko@kpi.ua, ORCID: http://orcid.org/00000001-9379-0061

Brzhezitsky Volodymyr, Doctor of Technical Sciences, Professor, Department of High Voltage Engineering and Electrophysics, National Technical University of Ukraine «Igor Sikorsky Kyiv Polytechnic Institute», Ukraine, e-mail: v.brzhezitsky@kpi.ua, ORCID: http:// orcid.org/0000-0002-9768-7544

Protsenko Olexandr, PhD, Associate Professor, Department of High Voltage Engineering and Electrophysics, National Technical University of Ukraine «Igor Sikorsky Kyiv Polytechnic Institute», Ukraine, e-mail: apro54@ukr.net, ORCID: http://orcid.org/00000002-7719-3336

Chumack Vadim, PhD, Associate Professor, Department of Electromechanics, National Technical University of Ukraine «Igor Sikorsky Kyiv Polytechnic Institute»,Ukraine, e-mail: chumack_kpi@ukr.net, ORCID: https://orcid.org/0000-0001-8401-7931

Haran Yaroslav, Assistant, Department of High Voltage Engineering and Electrophysics, National Technical University of Ukraine «Igor Sikorsky Kyiv Polytechnic Institute»,Ukraine, e-mail:y.garan@kpi.ua, ORCID: http://orcid.org/0000-0003-3242-9218 